\title{
Organizational Escalation and Retreat in University Athletics: Brand Insulation in Birmingham-Southern College's Transition to Division III Athletics
}

\author{
Adrien Bouchet \\ University of Tulsa \\ Michael Hutchinson \\ Coastal Carolina University
}

This case study will explore the theory of escalation of commitment within the context of intercollegiate athletics. This management-based theory has been used within business and foreign policy literature, but has yet to be explored through a sport management context. Recently, Birmingham-Southern College chose to reclassify its athletics programs from the Division I classification to the Division III classification. Utilizing qualitative methodology, interviews $(N=11)$ were conducted with a variety of university constituents. Findings revealed the following four themes: a) unsubstantiated outcomes regarding the benefits of Division I athletics, b) strained finances, c) presidential leadership, and d) perceived roles of a small, liberal arts institution. Discussion and application of the resulting thematic emergences with the escalation of commitment determinants will be discussed.

The common phrase "If at first you don't succeed, try and try again" stresses the value of persistence in American culture. While there are certainly benefits associated with persistence, problems arise when organizations and individuals remain financially committed to a project despite overwhelming evidence that their action is counterproductive, if not detrimental to a given organization. According to Ross and Staw (1993), organizational theory can be summarized in two fundamental questions: "1) how do we get organizations moving, and 2) how do we get them stopped once they are moving in a particular direction" (p. 701). Discontinuation of escalation behavior within organizations that have numerous stakeholders is particularly difficult. As a small, private liberal arts institution located in Alabama, Birmingham-Southern College (BSC) faced such a decision with regard to their athletics department. 
Intercollegiate athletic department budgets are rising at an alarming rate (Fulks, 2010). Increasingly, when athletic department revenues cannot cover expenses, institutional funds fill the gap. Institutional stakeholders believe that universities could spend financial resources devoted to athletics on programs that exemplify the university's mission, vision, and core values (Hearn, 2002). The problem is exacerbated at small, private institutions that often do not have the resources of large, public universities. These private institutions tend to remain committed to Division I athletics because of the national visibility that it brings to the institutional brand (Bouchet \& Hutchinson, 2010; Roy, Graeff, \& Harmon, 2008). When universities lend money to the athletics department, it results in a situation where they are investing scarce resources without any hopes of recouping their investment. This phenomenon-labeled escalation of commitment-occurs when institutions become entrapped in failing courses of action.

\section{Guiding Principles for De-escalation within College Athletics}

The financial obligations of fielding a Division I athletics program have caused administrators at smaller, private universities to pose the question "If expenditures exceed revenues in most college athletic programs, why are universities investing so much more each year in these programs" (Frank, 2004, p. 3). Recently, Vanderbilt University abolished its athletics department. While the athletic teams would still compete at the Division I level, the previous responsibilities of the athletics department would be absorbed by the university. Campus administrators cited the need for student-athletes to be more unified and better connected with the overall values of the university as one of the primary drivers for the nontraditional model of managing athletics (Zillgitt, 2004). While the transition was largely symbolic, few can argue that the university and its athletic programs have enjoyed resurgence.

Operating a Division I athletic department at small, private institutions is expensive, with only a small percentage of institutions that participate in Division I athletics earning a profit (Fulks, 2010). As previously addressed, universities that do not earn a profit are often subsidized by university funds. In these situations, a university can find itself in a cycle of escalation of commitment situations. Much of the research devoted to escalation of commitment theory has focused on situations involving the commitment of decision makers to losing courses of action (Simonson \& Staw, 1992). In a case study on escalation behavior, Ross and Staw (1993) examined a firm that leveraged one company's future on a nuclear power plant that never became operational despite many years and millions of dollars invested in this plan. The study exhibited that escalation situations are often the product of dynamic forces within the internal and external environment of the firm (Ross \& Staw 1993). However, Simonson and Staw (1992) stated that "much of the research in this area has focused on the determinants of escalation, and little attention has yet been given to the procedures that might help people avoid the escalation trap" (p. 419).

Referred to as 'de-escalation of commitment' (Drummond, 1995; Keil et al., 2000), there is a paucity of research devoted to the study of organizations that reverse their course of action after realizing they are entrapped in an escalating situation. 
Avoiding the escalation trap in college athletics is a subject that needs further investigation. Thus, the purpose of this study was to examine a small, private liberal arts college's (Birmingham-Southern College) decision to reclassify their NCAA Division I athletics program to an NCAA nonscholarship Division III classification. There are two important reasons for studying Birmingham-Southern's decision to exit Division I athletics for a Division III classification. First, the institution is one of a select few who have determined to leave the NCAA's Division I classification for nonscholarship Division III. Second, the lessons and strategies undertaken in this move need to be explored in an effort to reveal if such initiatives could be beneficial for other institutions seeking to break the cycle of escalation regarding athletics within the institutional setting.

\section{Theoretical Framework and Review of Literature}

\section{Escalation of Commitment Theory}

Escalation of Commitment theory states that there are "many instances in which individuals [and organizations] can become locked into a costly course of action" (Staw, 1981, p. 577). Staw (1981) continued by noting that "it is often possible for persons [or organizations] who have suffered a setback to recoup their losses through an even greater commitment of resources to the same course of actions" (p. 577). In escalation situations involving intercollegiate athletics, universities often find themselves participating at a level that does not make economic sense for the institution. Previous literature involving escalating behavior has focused on what academic scholars have termed determinants of escalation.

\section{Determinants of Escalation}

The main cause of escalation within organizations is the nature of the actual organizations themselves and not the individual people within those organizations (Staw \& Ross, 1987). In academic literature, escalation has been characterized as "the interplay of four sets of forces over time" (Ross \& Staw, 1993 p. 702). These four forces - project, psychological, social, and organizational—play a critical role within escalation situations. These determinants were part of a framework initially advanced in Ross and Staw's (1986) examination of British Columbia's decision to host the world's fair. A fifth determinant-contextual-was added in Ross and Staw's (1993) work concerning the Long Island Lighting Company's decision to build the Shoreham Nuclear Power Plant.

Project Determinants. Project determinants consist of assessing the economic prospects on many variables of a particular project in the future. This classification consists of such objective project aspects as closing costs, salvage value, the cause of the setbacks to its completion, and the economic merits of pursuing or discontinuing the initiative (Ross \& Staw, 1993). Northcraft and Neale (1986) revealed that accurate financial information is a necessity in an effort to form a failing course of action. Such uncertain project cost estimates make it difficult for individual decision makers to withdraw from a course of action. 
Psychological Determinants. Psychological determinants include reinforcement traps (e.g., difficulties in withdrawing from a previously rewarded activity), individual motivations (e.g., the need for self-justification), decision-making errors (e.g., attempting to recoup "sunk costs"), and information processing biases (e.g., tendencies to slant data in the direction of preexisting beliefs) (Platt, 1973; Ross \& Staw, 1993). According to Nisbett and Ross (1980), individuals have the tendency to bias facts in accordance with accepted beliefs and norms. As indicated by previous research, individuals are more likely to attribute negative outcomes to external as opposed to internal causes (e.g., Nisbett \& Ross, 1980; Staw, McKechnie, \& Puffer, 1983).

Organizational Determinants. Within the organizational determinant, variables include the degree of public support for an organizational project, the level of economic and technical "side-bets" (i.e., additional investments incurred by the organization with respect to the project), and the extent of the project's incorporation of and alignment with organizational values and objectives (Goodman, Bazerman, \& Conlon, 1980; March 1978; Pfeffer, 1981). Within the intercollegiate athletics setting, an example of a side-bet might be how universities currently use athletic programs as a vehicle for branding/marketing the institution instead of the original intent of serving as student sponsored competitions.

Social Determinants. This determinant consists of interpersonal processes that could potentially lead to excess commitment (e.g., the desire to justify losing projects to potentially hostile audiences), modeling others' behavior in comparable situations, and cultural norms favoring consistent or strong leadership (Brockner, Rubin, \& Lang, 1981; Fox \& Staw, 1979; Ross \& Staw, 1993; Staw \& Ross, 1980). Simply put, social determinants refer to an unwillingness to forfeit credibility in the instance of unexpected losses. Ross and Staw (1986) acknowledge that "decision makers may persist in a course of action not only because they do not want to admit to themselves that they have made a mistake, but because they may also be especially hesitant to expose their errors to others" (p. 277). By removing athletic programs from their NCAA Division I status, a university may lose credibility with their alumni, students, peer institutions, and, certainly, the media.

Contextual Determinants. Contextual determinants are defined as issues "larger than the organization itself, involving forces beyond the organization's boundaries" (Ross \& Staw, 1993, p. 719). While not a portion of the original Ross and Staw (1993) model, contextual determinants play a vital role in the study of organizations with many stakeholders. This is certainly true regarding the study of higher education and athletic departments. As an example, Ross and Staw's (1993) study of the Shoreham nuclear power plant noted that "the decision to construct a nuclear power plant became larger than the organization itself, involving forces beyond the organization's boundaries" (p. 719). Examples included relationships between state and national energy regulation agencies, the country's views toward energy, and the local and national political environment. Since athletic department reclassification involves numerous external stakeholders, contextual determinants played an important role in this investigation. 


\section{De-escalation Literature}

Although escalation situations have been examined from differing contexts, there is limited research involving de-escalation situations. Drummond (1995) explored the de-escalation of a law firm and hypothesized that de-escalation involves a relationship between power, commitment, and the probability of withdrawal. She acknowledged that if escalation theory suggests persistence is a function of the decision maker's feelings of potency, then de-escalation reflected a sense of powerlessness. Further, Drummond noted that "withdrawal is most probable under conditions of low commitment and high perceived power" (p. 278). In lay terms, participants are most likely to withdraw from an escalating situation when there is little financial or personal investment, and they have a high degree of influence within the organization.

Another study pertaining to de-escalation involved Montealegre and Keil's (2000) investigation of an information technology firm. Montealegre and Keil (2000) defined de-escalation as a process of redirection as well as abandonment. Simply put, a project does not have to be abandoned for de-escalation to occur. In certain instances, participants can de-escalate a project by redirecting the project to a more successful outcome. Montealegre and Keil (2000) acknowledge that "while redirection cannot guarantee that the project will be successful, it does signal a reduction of commitment in response to a failing course of action" (p. 418). Their investigation, which explored the implementation of a state of the art baggage system at the newly constructed Denver International Airport, broke de-escalation into four phases. These four phases consisted of a) problem recognition, b) reexamination of a prior course of action, c) search for alternative courses of action, and d) implementing an exit strategy.

Within each of these phases, the authors recognized key triggering activities. In the "problem recognition" phase, the prominent triggering activities were recognizing negative feedback and responding to external pressures. The "reexamination of prior course of action" phase included triggering moments like clarifying and redefining the magnitude of the problem. The "search for alternative courses of action" phase consisted of identifying and legitimizing a new, alternative course of action, along with managing subsequent impressions. In the final phase, "implementing an exit strategy," the triggering activities consisted of appealing to stakeholders and de-institutionalizing the project. Such de-escalation strategies can be observed in the reclassification of Birmingham-Southern's athletics department.

\section{History of Athletics at Birmingham-Southern College}

Athletics has always played an important role at Birmingham-Southern College. Following the consolidation of Southern College and Birmingham College to form the present-day college in 1918, the Birmingham-Southern football team won conference championships in 1932, 1934, and 1937, enjoying a perfect season in 1934 which included a road victory over Auburn University (Cole \& Wagnon, 2007). However, following the conclusion of the 1939 season, the football program was disbanded as a victim of high cost and undue influence from external stakeholders. While football was no longer played on campus, other programs thrived at 
Birmingham-Southern. A longtime member of the National Association of Intercollegiate Athletics (NAIA), Birmingham-Southern enjoyed success in all sports. The basketball team won the NAIA national championship in 1990 and 1995, and the baseball team won the national championship in 2001. Due to such athletic success, many stakeholders believed that Birmingham-Southern had outgrown the NAIA and subsequently petitioned the NCAA for acceptance at the Division I level.

Internal stakeholders agreed that membership in the NAIA was no longer a viable option for the college. Campus administrators relished the idea of competing against universities that better represented their idea of where Birmingham-Southern stood in the hierarchy of higher education. In May of 1999, the Board of Trustees voted to move the college into Division I athletics and accepted an invitation to join the Big South Conference. One of the benefits of membership in the Big South Conference was that the winner of the conference basketball tournament received an invitation to the NCAA basketball tournament. Institutional administrators liked the idea of the potential national exposure received in the instance of a conference championship.

In addition to the increased exposure, another reason for the move was the college's growing endowment. In the late 1990s, fueled by the rise in the stock market, the endowment had grown to over $\$ 300$ million. The rise in the endowment allowed administrators to consider options for increasing visibility from an institutional marketing perspective. Similar to other private institutions, Birmingham-Southern hoped to use their Division I status to increase visibility, boost student enrollment, and increase donations.

Transitioning from NAIA to Division I required a significant increase in the athletic department budget. In Birmingham-Southern's initial year (2001) at the Division I status, the athletic department budget was $\$ 6.5$ million which helped fund 116 scholarships. The capital improvements budget was significantly increased to get Birmingham-Southern in compliance with Division I standards. From 1999-2001, the college invested \$3.5 million into existing athletic facility improvements. Although the college's endowment was growing because of the strong economy, these investments would prove to be premature in nature. Due to growing financial concerns, the Birmingham-Southern Board of Trustees voted in May of 2006 to reclassify the college's intercollegiate athletics program from Division I to nonscholarship Division III (Cole \& Wagnon, 2007). The college cited both financial concerns and a desire to associate Birmingham-Southern with peer liberal arts institutions as reasons for the transition.

The reclassification of athletics at Birmingham-Southern College was undertaken due to both the increasing costs of operating a Division I athletics program and the desire to associate the college with like minded peer institutions. As the initial investigation that addresses de-escalation within the context of intercollegiate athletics, this study explored how a small, private liberal arts college reclassified its athletic department. Based upon the theoretical framework and review of existing literature, this study sought to answer the following research questions:

R1. What were the escalation determinants that contributed to BirminghamSouthern's decision to reclassify its athletics programs to Division III?

$\mathrm{R} 2$. Which escalation determinants were more influential in the decision to reclassify the athletics program? 
R3. What role does the internal and external environment play in BirminghamSouthern's decision to discontinue investments in their Division I athletic program?

\section{Method}

Many of the early empirical studies on the escalation phenomenon were laboratory based. These studies limited the scope of escalation to testing individual level variables. Because of these limited studies, Ross and Staw (1986) noted that "processes such as institutionalization have been virtually ignored in the literature, even though they may underlie many organizational examples of escalation" (p. 278). However, recent literature has focused on testing this theory through field-based qualitative case studies (Drummond, 1995; Montealegre \& Keil 2000; Ross \& Staw, 1986, 1993). By providing a specific example, this study will examine de-escalation in an organizational setting. This study continues the trend of observing escalating and de-escalating scenarios from a qualitative inquiry perspective. The case study method has been chosen because it represents an opportunity to test this theory during a set period of time.

\section{Case Study Methodology}

The case study research method has been used as a research tool in a variety of academic disciplines. According to Soy (1997), the qualitative case study method has been widely used by social scientists for purposes of examining "contemporary real-life situations and provide the basis for the application of ideas and extension on methods" (p. 1). The case study method is appropriate when examining a real life scenario during a certain period of time. Yin (1984) notes that the case study research method should be applied when investigating "a contemporary phenomenon within its real-life context, when the boundaries between phenomenon and context are not clearly evident, and in which multiple sources of evidence are used" (p. 23). Previous literature has noted a paucity of field-based research on escalation and de-escalation situations.

Academic researchers have observed that case studies help strengthen a subject that has become detached from the field and allow for the search of broad-based patterns regarding escalation and de-escalation scenarios (Lipshitz, 1995; Ross \& Staw, 1986). As such, the case study approach is an appropriate research method for de-escalation investigations. Staw (2005) notes that there are three criteria for conducting a field-based study regarding escalation situations. The three criteria are a) ongoing as opposed to a one-shot decision, b) ambiguous or negative feedback, and c) an opportunity to commit additional resources over time. During the time period of this research investigation, Birmingham-Southern fit all three of these criteria.

Interviews were selected as the primary source of data collection because they provide a detailed history of this time period at Birmingham-Southern. Physical documents were used as a secondary source to fill any gaps in the information provided by participants. Documents used for this study included popular press articles, newspaper articles, university press releases, and athletic department press releases. This secondary data collection source obtained general background information about the subject matter. 


\section{Participants}

Purposive, nonprobability sampling was implemented for this study. This investigation consisted of data provided by university administrators, athletic department personnel, current and former faculty members, students, university board members, and a local media member. Eleven $(N=11)$ interviews were conducted in a semistructured format with interviewees consisting of seven males and four females (For demographic information, see Table 1). In the initial phase of the research, an e-mail was sent to interview participants. The e-mail included a description of the researcher's background, outline of the research agenda, and request for an interview at the individual's earliest convenience. The criteria used to select these interviewees included having an in depth knowledge concerning the decision-making processes regarding the subject matter at both the university and athletic department levels. In the initial correspondence, participants were made aware that the interviews would be recorded and transcribed. Seven of the eight participants requested their personal identity to remain confidential. One individual, University President David Pollick, was willing to be identified as a participant and was subsequently linked to statements used in the findings and discussion sections.

\section{Data Collection}

Interview times ranged from 30 to 45 minutes in length. Data were collected via on-campus interviews and telephone interviews. Interviews were audio-taped and transcribed verbatim following the completion of each individual interview. During and immediately following interview dialogue, detailed notes were taken regarding the subject matter. Upon completion of the interview dialogue and transcription, a follow-up phone call was initiated with the interviewee to further discuss the main points of the interview. This was conducted to ensure correct and accurate understanding of interviewee's insights and experiences. The final question set consisted of thirteen primary interview questions, with numerous supporting questions that

\section{Table 1 Demographic Information of Interview Participants}

\begin{tabular}{lll}
\hline Stakeholder Category & Race/Ethnicity & Sex \\
\hline University President & Caucasian & Male \\
Board of Trustee Member & Caucasian & Male \\
Board of Trustee Member & Caucasian & Male \\
University Administrator & Caucasian & Female \\
Athletic Administrator & Caucasian & Male \\
Athletic Coach & Caucasian & Male \\
Faculty Member & Caucasian & Female \\
Faculty Member & Caucasian & Female \\
Current Student & Caucasian & Male \\
Current Student & Caucasian & Female \\
Local Media Member & Caucasian & Male \\
\hline
\end{tabular}


emerged throughout the data collection process (Kvale, 1996; Patton, 1990). A list of the interview question set can be viewed in Appendix A. Sampling was considered complete once no new themes emerged from the data, indicating a saturation of the data. Depending upon the scope of the investigation, this saturation point (i.e., exhaustion within the data) informs researchers that additional interviews may or may not prove beneficial (Singer, 2009).

\section{Data Analysis and Trustworthiness of the Study}

In an effort to ensure a thorough and accurate representation of the analysis process, data gathered from the interviews were arranged by implementing emergent category designation. Implementation of emergent category designation requires the following five steps: a) read the first unit of data, b) read the second unit of data, c) proceed until all the units have been assigned to a category, d) create category titles and/or descriptive sentences that make the category unique, and then e) start over (Erlandson, Harris, Skipper, \& Allen, 1993). Before the initial coding of the data, transcriptions were read thoroughly to become familiar with interviewees responses (Marshall \& Rossman, 1995). Following this preliminary organization technique, the analysis began by dissecting the data into 'units' of information. According to Lincoln and Guba (1985), a unit is a small piece of information that can stand alone and remain intelligible. Such units can be as short as a few descriptive words or as long as a full paragraph. The final step in this process allowed researchers to continually reassess the categories that had emerged from the data.

Trustworthiness within a qualitative investigation has been described as a quality of the investigation and its findings that make it significant to an audience (Patton, 2002). Glesne (1999) suggests that trustworthiness within a research endeavor needs to be addressed when designing a research investigation. Schwandt (1997) developed four potential criteria for assessing trustworthiness: credibility, transferability, dependability, and confirmability. This investigation used two of the four recommended criteria: credibility and transferability. In an effort to fulfill credibility, the techniques of triangulation, peer debriefing, and member checking were implemented (Lincoln \& Guba, 1985; Mertens, 1998). Patton (2002) defined triangulation as "the use of a variety of data sources in a study" (p. 247). Personal interviews and the examination of documents were data collection methods used to fulfill the triangulation technique. Credibility was further enhanced by audiotaping and verbatim transcription of each interview. The peer debriefing technique was the second measure employed to ensure credibility within this investigation. Individuals within the university and researcher's academic program were used to discuss emerging themes and provide insight related to data collection techniques. Finally, member checks were applied to verify and confirm an accurate understanding of participant responses. Interview participants were e-mailed a copy of their interview transcript to confirm a correct transcription of the interview dialogue.

The second trustworthiness criteria addressed in this investigation was transferability. This criteria provides readers with defining characteristics of the research setting to determine the applicability to other situations (Lincoln \& Guba, 1985). One manner in which this criteria can be accomplished is through thick, rich description of the research setting. As provided in the review of literature, a historical description of Birmingham-Southern athletics was thoroughly described. 
These descriptions provide future researchers a snapshot of the setting in which the research was conducted, as well as offer them the opportunity to make the necessary adjustments in their own research investigations.

\section{Findings}

Data collected revealed four main themes regarding Birmingham-Southern's transition from Division I athletics to nonscholarship Division III: a) unsubstantiated outcomes regarding the benefits of Division I athletics, b) strained finances, c) presidential leadership, and d) perceived role of a small liberal arts institution. This section will discuss the categories and roles they played in the college's reclassification of athletics.

\section{Unsubstantiated Outcomes Regarding the Benefits of Division I Athletics}

Interviewees stated that the reason for the move to Division I was influenced by pressure from a select group of donors; however, administrators asserted that increased exposure was the primary reason used to justify the move. Interviewees noted that the increase in exposure would come from qualifying to participate in the NCAA Division I basketball tournament. Institutional constituents hoped that the college's increased exposure would help increase the college's endowment and boost student enrollment. As such, one faculty member noted the following:

We had outlived our usefulness in the NAIA. We needed to seek better competition. We thought we could combine the goal of competing at the NCAA Division I classification with a rebranding of the school. Ultimately, the first goal (increased exposure) was met, but not the second (increase endowment and enrollment).

It was the belief of campus administrators that these goals to rebrand the college, increase the endowment, and increase the student enrollment were not being met by the move to Division I. When asked why the new administration at Birmingham-Southern would change its course regarding the branding of the college after participating in Division I for only four years, an administrator stated:

The underlying reason was simply that we had four or five donors that thought bigger is better in regards to athletics. They were being disingenuous regarding the reasons for undertaking the move. The bottom line was we just could not afford to participate at the Division I level. It didn't work. There was no discernable increase in either donations or student enrollment.

Upon attaining presidency in 2004, David Pollick was quick to point out that enrollment actually increased when the college announced its transition from Division I to Division III. While there is no data pointing out that the increase was due to the move to Division III, the college used some of the resources previously expended on athletics to recruit and fund academic scholarships. Before the Division III transition, the 2006 incoming class included 326 students for a total undergraduate enrollment of 1,207. The year after the move was announced, there 
were 506 new students and a projected enrollment of 1,318 (Powers, 2007). Beyond the potential positive effects on enrollment from the transition, the college began to experience increased pressure from a financial perspective.

\section{Strained Finances}

Interviewees were careful to acknowledge the role of external stakeholders regarding the move to Division III athletics. One administrator stated:

In order to get the board approval, we had to frame the move to Division III from an economic argument, not a philosophical one. In this part of the country, a philosophical argument against Division I athletics is just not going to win.

The interviewee noted that the popularity of college sports in the southeastern portion of the country, particularly football, forced Birmingham-Southern to define the argument in financial terms. As an interviewee in this investigation, President Pollick noted that the move to Division III would allow the college to discontinue subsidies to the athletics department. This in turn would help the college shore up their increasingly precarious financial position. Dr. Pollick stated "when the decision to move to Division I was made in 1999, the school's endowment was at record levels due to a strong stock market." However, this was not the case in 2004 and Pollick could see limited reasons from spending 13\% of the institutional budget on 116 scholarships. There was a belief among administrators interviewed that the Trustees in the previous administration had not been fully informed regarding the college's strained finances. When trustees were presented with the proper financial information, the decision to change classifications was clear. Concerning this matter, an executive administrator stated:

The Board of Trustees was not fully aware how bad school finances were. The credit rating agency (Name) had downgraded our bonds. We were running a $\$ 6.5$ million deficit. Not all of it was athletics, but a significant portion was because we could not cover the costs of participating in Division I athletics. We had two choices regarding covering the deficits. One, we could undertake emergency fundraising or two, take it out of the endowment. Neither of these options was pleasant.

By moving to Division III, the college was able to significantly decrease the money allotted to athletics. Previously, Birmingham-Southern had to subsidize the athletic department for any budget shortfalls. While those losses were acceptable during the strong economy of the late 1990s, they were deemed unacceptable during the economic slowdown in the early 2000s. Administrators had stated that moving athletics from Division I to Division III would decrease the athletic department budget from $\$ 6.5$ million to $\$ 3.5$ million. This projection was more acceptable to the president and Board of Trustees. Two administrators noted the following concerning this topic:

The economics of college athletics are simple: very few schools make money. That being said, someone has to pay for the shortfall. The shortfall is almost always covered by the school's central fund. The current administration made a decision to stop covering the losses. 
The financial reality of us entering Division I never made economic sense. There was no long term solution regarding the question of how do we make Division I financially viable. A handful of donors agreed to basically provide the seed money for the initial move to Division I, but we did not ask for a long range financial commitment from them after that money was gone. When an athletic department is not self-sustaining, the fate of athletics is left to university leaders.

The consensus agreement among those interviewed was that the college simply did not have the financial resources to compete in Division I and needed to reassess the direction of the athletic department.

\section{Presidential Leadership}

It is an old adage that the quickest way to kill an idea on a college campus is to form a committee to study the issue. Previous attempts to reclassify athletics at other institutions have failed when committees were formed. Birmingham-Southern's administrators were determined to avoid the forming of a committee to study reclassifying the athletics department. President Pollick noted that there is always inertia against change on a college campus. During an interview with the president, Dr. Pollick stated:

Typically, when administrators of non-profit entities cannot deal with the specifics of a problem, they attack the process. I worried that the forming of a committee would lead to issues being discussed that had little to do with the subject matter. That is just how higher education works. Oftentimes, we defer on the tough questions.

Pollick was determined to address the issue only with select members of the Board of Trustees. He stated: "I'm on my third college presidency. It's very clear in my mind what our institution stands for and what level our athletics program should be participating in." Dr. Pollick asked that the board reach a decision within 90 days to avoid the standard institutional course of action which is to form a committee to further study the issue of reclassifying the athletics department. One administrator stated:

This is especially true when dealing with big time college athletics where the media has strong influence. On a college campus, the quickest way to not do something is to form a committee. When a committee is formed, your opposition has time to build a case.

Pollick explained that one of the major reasons why the college was able to successfully transition from Division I to Division III was because the decisionmaking process involved a relatively small group of individuals. As such, Pollick stated "I took my initial findings to the Chair of the Board of Trustees. After he reviewed my concerns, he polled a small group of Trustees and the decision was made to proceed." Administrators interviewed discussed the recent reclassifying attempts at Centenary College, Rice University, and Tulane University. Only Centenary was successful in reclassifying their athletics program to the Division III status. In the case of Rice and Tulane, attempts ended when the university formed 
committees to investigate the issue. One interviewee noted that "this gave time for the Division I supporters to marshal resources, mainly through the media, to stop the reclassification efforts."

To win faculty support, it was essential that the college align itself with institutions of similar mission, vision, and core values, thus signifying the importance of displaying a consistent institutional brand. This was not an easy task, considering the lack of Division III conferences in the southeastern region of the United States. Dr. Pollick stated that "through some back channels, we called various Division III conferences to see if there would be interest in having Birmingham-Southern College as a member of that particular conference." One administrator noted that "the key to the whole move was finding a conference that fit both our schools mission and was also geographically suitable for our student-athletes." This administrator credited Pollick with understanding the political aspect of reclassification-the key to gaining admission in a good Division III conference was football.

With the money saved from the move to Division III, the college was able to reinstate the football program. A portion of football's reinstatement was due to the desire to join the Southern Collegiate Athletic Conference (SCAC). The addition of football was considered important regarding admittance to the SCAC, where the majority of member institutions sponsored the sport. One interviewee stated "Adding football was a good move for the school. It plays an important role on college campus' in the South and I believe helped us get into a good Division III conference." The general feeling among administrators was that the addition of football would help ease political forces that might oppose reclassification. One faculty member stated:

I always thought that adding football was a smart way for the administration to placate students and alumni regarding the move to Division III. It also helps that at the non-scholarship Division III classification, all student-athletes, including football players, are paying to attend your college.

Further, another faculty member noted:

The key arguments against the move were that we had just invested millions in new athletic facilities to get up to Division I standards and he [Pollick] just doesn't like sports. With the addition of football and a plan to use the new facilities for Division III athletics, he countered those arguments.

As exhibited by the above quotes, campus administrators felt that Division I was not where Birmingham-Southern needed to be housed. The reasoning for such beliefs resided in the following theme which related to the perceived role of the institution.

\section{Perceived Role of a Small Liberal Arts Institution}

Then BSC Board of Trustees Chair James T. Stephens stated "One of the things we considered in the decision [to reclassify to Division III] was which athletics division is indeed the right fit for an institution of our size, of our academic mission and quality, and of our financial resources" (Cole \& Wagnon, 2007, p. 26). It was apparent from interviewees that while the economics of Division I was given 
as the central reason for the move, the current administration had differing views regarding the mission of a liberal arts college from the previous administration. As previously mentioned, in an effort to win faculty support, it was essential that the college align itself with institutions of similar mission, vision, and core values.

Once firmly committed to Division III athletics, Birmingham-Southern found a home in the SCAC. The SCAC is comprised of private institutions of high academic distinction, located mostly in the Southern part of the country. Members include such four-year institutions as Rhodes College, Centre College, DePauw University, and Trinity University. Almost all the member schools have Phi Beta Kappa chapters. One faculty member stated that "having a Phi Beta Kappa chapter on this campus is incredibly important to this school and the accreditation process." In Pollick's opinion, this classification and this conference would better position the college, both athletically and academically, for the future.

\section{Discussion}

\section{Project Determinants}

According to Ross and Staw (1993), project determinants often include closing costs, sunk costs, and the economic merits of pursuing or dropping the course of action. Previous literature regarding escalation has noted that the financial and economic structure of a project can determine whether an organization will persist or withdraw from a situation (Ross \& Staw, 1986). Evaluating Birmingham-Southern's decision to abandon Division I on these merits, one can begin to understand the college's decision from a de-escalation perspective. The closing cost for the decision to leave Division I for Division III consisted of the college agreeing to honor all scholarships to student-athletes for four years. The college believed that this was a fair decision, as these student-athletes signed a scholarship agreement with Birmingham-Southern to participate in Division I athletics. This cost was reduced once most student-athletes decided to transfer to other Division I institutions. The college also agreed to honor all coaches' contracts. These costs are what academic administrators term a "one-time write-off," and went a long way toward ameliorating the financial strain on the college.

In college athletics, most sunk costs reside in facilities. Sunk costs are defined as costs that cannot be recovered once they are incurred (Arkes \& Blumer, 1985). According to Ross and Staw (1993), the investment of monetary funds in physical structures usually indicates a willingness to invest additional funds in a particular initiative or endeavor. This was not the case at Birmingham-Southern where facilities proved to be an asset. Due to the transition from Division I to Division III, the college had invested $\$ 3.5$ million in capital costs to upgrade their facilities. The capital investments would have been a larger issue had the college dropped athletics altogether, rendering facilities obsolete. Previous de-escalation literature notes that project redirection is a form of de-escalation. Montealegre and Keil (2000) state that "while redirection cannot guarantee that the project will be successful, it does signal a reduction in commitment in response to a failing course of action" (p. 418). Such a move away from Division I allowed the college to simply redirect resources, in this case facilities, for Division III use. 
When discussing the role played by project determinants, scholars note the importance of reliable financial information in stopping an escalating situation. Interviewees unequivocally stated that the Board of Trustees were not given the necessary facts regarding both the full costs of operating a Division I program and the financial health of the college. Northcraft and Neale (1986) revealed that clear and evident financial information can be necessary for individuals and organizations to withdraw from losing courses of action. Once the Board of Trustees was given the correct financial information, the decision was made to reclassify.

\section{Psychological Determinants}

An additional factor in escalation situations is the role of reinforcement traps. Reinforcement traps can be defined as situations in which "people assume, because of their histories of success, that losing courses of action will turn around" (Ross \& Staw, 1993, p. 716). As acknowledged by Platt (1973) and March (1978), individuals holding top leadership positions are potentially prone to these reinforcement traps. Administrators at Birmingham-Southern were guilty of succumbing to such reinforcement traps. As an example, these administrators allowed a small group of donors to effectively decide the direction of the college's athletic programs. These donors had previously been quite successful in making decisions (along with the president) that allowed the college to become a nationally ranked liberal arts institution. Research shows that individuals often bias facts toward a preferred outcome (Nisbett \& Ross, 1980). In the case of Birmingham-Southern, there were clearly mistakes in the information processing involving the transition from NAIA to a NCAA Division I classification. Recall the situation in which the Board of Trustees was led to believe that the move to Division I would lead to increases in student enrollment and endowment funds. In essence, administrators allowed themselves to believe what they wanted to believe regarding the benefits of Division I membership.

The decision to move from NAIA to NCAA Division I came at the conclusion of the most prosperous era (both financially and academically) in school history. The college's administrators had a prolonged and steady tenure at the institution which made them susceptible to reinforcement traps. In other words, this finding was in line with Ross and Staw (1993), in which they state "With such a personal reinforcement history, it may have been difficult for him to conceive of a course of action not eventually being successful" (p. 716). In retrospect, BirminghamSouthern was guilty of an overstatement of the benefits for such a move to Division I. Simply put, administrators wanted the move to be successful, so they chose to look at the facts that would reinforce such an outcome. When the benefits of Division I did not materialize, administrators were forced to either continue funding athletic programs at a classification the college could not afford, or admit a decision-making error and reclassify athletics to the nonscholarship Division III level.

Escalation literature has found that many firms retained unprofitable business operations with steadily mounting losses for years without divesting them (Shimizu \& Hitt, 2005). As an example, Certo, Connelly, and Tihanyi (2008) note that "in several cases the arrival of outside executives, who were not involved in the initial acquisition decision, was needed to hasten divestiture of the failing division" (p. 11). This was certainly true in Birmingham-Southern's case, where the arrival of a new president-Dr. David Pollick-started the discussion concerning a move to 
Division III. As a former college president at two small institutions, Dr. Pollick brought a working knowledge of higher education and athletics to the Division III level. As an outsider to Birmingham-Southern, he was not tied to the course of action (move to Division I) that was decided before his arrival.

Recently, Rice University and Tulane University studied the feasibility of reclassifying their athletic departments. These attempts ended when both institutions decided to remain in the Division I classification (Rice University Report 2004, Tulane University Report 2003). Administrators at Birmingham-Southern acknowledged how the situation at both Rice and Tulane played a part in shaping their decision-making process. It was their belief that the forming of committees played a significant role in both institutions remaining at the Division I level. Dr. Pollick was determined not to let that happen at Birmingham-Southern. Pollick was unequivocal in stating the most important factor in making the decision to reclassify the athletics program was the fact that the initial decision-making process was simply him and select board members. This decision-making process eliminated any organizational inertia that might have existed had the decision required committee approval. In de-escalation scenarios, the perception of power is often a persuasive strategy. Previous de-escalation literature has noted that "withdrawal is most probable under conditions of low commitment and high perceived power to enact withdrawal" (Drummond, 1995, p. 278). Due to the brief time period at the Division I level, the faculty and campus administrators had a low commitment to the classification. Dr. Pollick used his authority to better align athletics to the central mission, vision, and values of a liberal arts institution.

\section{Social and Organizational Determinants}

In an article published by the Harvard Business Review entitled Knowing When to Pull the Plug, Staw and Ross (1987) state that "one way to reduce the commitment to a losing course of action is to replace those associated with the original policy or project" (p. 5). By removing the administrative leadership responsible for the initial course of action, organizations can abolish some sources of the original commitment (Staw \& Ross, 1987). As evidenced by the findings, this was the case at Birmingham-Southern, as the current president and chairman of the Board of Trustees were not in their positions when the decision was made to compete at the Division I level. Therefore, President Pollick did not have to manage what scholars have termed "external justification" regarding escalation situations.

External justification can be described as the need for decision makers to rationalize actions to other parties (Ross \& Staw, 1993). In essence, when an individual inherits a problem, it is easier for that person to take action because he/she does not have a vested interest in a particular direction of the project. As neither Dr. Pollick nor the principal leadership of the Board were involved in the original decision to reclassify the athletics program, they did not have a vested interest in adhering to what rapidly became a losing course of action for the college. As Drummond (1995) noted, withdrawal is more likely in scenarios where there was low commitment and high perceived power. At the time of the decision to leave Division I, Pollick was new to the college and exhibited high perceived power, while the college had only participated in Division I for a short period of time, thus displaying a low commitment. This coupled with the economic downturn allowed Pollick the freedom to not rationalize the decision to certain internal and external stakeholders. 
Another social determinant of commitment, as described in the literature, pertains to the desire not to lose face or credibility (Ross \& Staw, 1986). Due to the relatively short period of time Birmingham-Southern participated in Division I athletics, this characteristic was not applicable. One of the primary factors in reclassifying an athletics program is the embeddedness athletics has on an individual college campus. Due to their long history on campus, these athletic programs become institutionalized. Previous escalation literature has shown a correspondence between institutionalization and de-escalation. Ross and Staw (1993) note that institutionalization is considered to be an organizational determinant. As Birmingham-Southern had competed at the Division I level for a short period of time, institutionalization was not a factor. The college had simply not established itself as a full fledged member of either the conference or Division I long enough to suffer any lasting effects of changing classifications.

One could argue, and indeed campus administrators did, that BirminghamSouthern actually enhanced the academic brand reputation with the move by joining a Division III conference that was comprised of like minded institutions. As previously mentioned, for example, nearly all the universities that participate in the SCAC have Phi Beta Kappa chapters which serves as a point of ride with university administrators, faculty, and alumni. Montealegre and Keil (2000) note that "it is not unreasonable to conclude that reframing, or redefining, the problem could be a useful tactic for promoting de-escalation" (p. 434). By highlighting the academic merits of the decision to move to Division III and adding a football program, Pollick successfully reframed the decision.

Dr. Pollick and the chairman of the Board of Trustees made what can be described as an economic conventional wisdom argument to the college's Board of Trustees. After reviewing the institution and athletic department financial records, it was clear that Birmingham-Southern could not continue devoting financial resources to a Division I athletic program. The financial situation at the college represented a shock which Drummond suggests "may be necessary to galvanize decision makers into action" (Drummond, 1995, p. 277). Since Birmingham-Southern did not sponsor a football program at the Division I level and the basketball program only participated for a short period of time, political support played a limited role in the reclassification decision. This does not simply imply that everyone was happy with the decision to transition from Division I to Division III. To the contrary, a small (but vocal) group of board members felt that Birmingham-Southern had not participated at the Division I level long enough to properly determine the benefits of this level of competition. Included in this group were trustees that had contributed significant donations to upgrade the athletic facilities at the college. These same trustees were not pleased that they had not been consulted concerning the move to Division III.

\section{Organizational Exit}

\section{A Strategic Plan for Reclassification}

How does a university president address and act upon the sensitive question of athletic department reclassification? For incoming Birmingham-Southern President David Pollick, it started with a simple question: Why is the institution spending 
$13 \%$ of the operating budget on less than 200 students? Although one could argue that Birmingham-Southern students enjoyed the increased exposure afforded to the college because of participating in Division I, Dr. Pollick believed the high percentage of the college's budget devoted to subsidizing athletics could be better spent on academic scholarships. As such, devoting financial resources to academic scholarships would serve to better fulfill the institutional mission, vision, and values.

Pollick believed that funds could be better spent on recruiting and awarding academic scholarships to qualified students. By devoting more money to academic scholarships, the college and its students would all benefit. However, Pollick was not naive to the need for a strategic plan regarding what was sure to be a controversial plan. The strategic plan revolved around faculty support, media, and the addition of football. In the case of Birmingham-Southern, the administration recognized that because of its Division I classification the media would become a stakeholder. According to Freeman (1984), a stakeholder by definition is "any group or individual who can affect or is affected by the achievement of the organization's objectives" (p. 46). As is often the case in college athletics, Birmingham-Southern's decision to reclassify an athletics program to the Division I status became a major story. The subsequent decision to abandon Division I athletics for nonscholarship Division III became an even bigger story in the national, regional, and local news.

In the national press, legendary sports writer Frank Deford (2007) praised Dr. Pollick for supporting academics at a time when universities were sinking unprecedented financial resources into their athletic programs. Deford, who once commented that Alabama was "the holy epicenter of college sport," admired Pollick's stance on such a tough decision. The local press took a different tone and the president was vilified as a carpet bagging academic that cared little for athletics. Pollick would later state that not one local sports writer called him to ask for his reasons for the move. He added that the first reporter to call was from the business section of the Birmingham News.

\section{Insulating the Brand at Birmingham-Southern}

Pollick's acknowledgment that Birmingham-Southern should transition to Division III status for purposes of better aligning athletics with the central mission, vision, and core values of a liberal arts institution also indicates the importance of maintaining the academic brand reputation of a university. As an element of building and maintaining a desired brand image, the core values of an organization have emerged as fundamental characteristics that define the brand of an organization (Moser, 2003; Urde, 2003). Research reveals the necessity of commitment and consistency to the core values of an organization, as a failure to do so will disillusion stakeholders, further diminishing organizational brand credibility (Collins \& Porras, 1996; Sull \& Spinosa, 2007). Although the majority of Division I institutions submit to the traditional model of big time college athletics, universities such as Vanderbilt have chosen to implement a nontraditional model for preserving a consistent athletic and university brand.

As discussed at the outset, the model set forth at Vanderbilt in 2003 eliminated the Athletics Director position and joined varsity athletics with the Division of Student Life and University Affairs. According to then Chancellor E. Gordon Gee, the university and the athletic department had become "isolated and disassociated" 
from one another, specifically noting that the "value system of the university and the value system of the athletic department have diverged" (Zillgitt, 2004, p. 1). Although much debate ensued concerning this unorthodox model for administering and overseeing a Division I intercollegiate athletics department, structural modification was necessary to more effectively integrate athletics into academics and campus life. Certainly, Vanderbilt's model for athletics management is not for every institution of higher learning. Numerous stakeholders were concerned about the potential for de-emphasizing athletics at the university. Yet, the opposite proved to be true in the case of Vanderbilt, as centralizing athletics within the university exhibited the high priority placed upon athletics.

Pollick's mindset of "bigger not necessarily being better" further indicates the necessity of returning to the original mission and core values of a private, liberal arts higher learning institution. Certainly, Pollick understood the importance of athletics as it related to the college and representing a portion of the institutional brand. Nevertheless, current operation of a Division I athletics department at a private, liberal arts institution such as Birmingham-Southern does not appear to reinforce that consistent, singular brand to stakeholders and external publics. Although Vanderbilt's model of placing athletics under the authority of university administration is not necessarily the appropriate solution, a similar strategy for purposes of financial and brand management may prove beneficial for an institution such as Birmingham-Southern.

\section{Conclusion}

As Division I athletics continue to move further toward a delineation between the haves and the have nots, the decision regarding which NCAA athletic classification institutions ought to participate in continues to grow. The chosen classification is heightened by higher education's precarious funding in tough economic times. The principal strategy Birmingham-Southern administrators applied in de-escalating its athletics program was based on an economic argument. Primarily due to the nationwide economic downturn, the college simply could not continue to subsidize Division I athletics. When debating the merits of the various classifications offered by either the NCAA or NAIA, it is imperative for university administrators to investigate the viability of financial success. If athletics is not going to be financially feasible, administrators need to understand that the difference between what an athletics department costs to operate and the revenue generated is more often than not going to be augmented by the institution's central funds. However, using the university's central funds to cover athletic expenses when academic programs are suffering is a difficult argument to defend.

The authors wish to note that we (and other theorists) approach escalation of commitment from the perspective adopted in this paper. However, we recognize that other positions could also be adopted. It is worth noting that we didn't originally approach this study from a standpoint of escalation being a "negative". Rather, we were simply exploring the phenomena of escalation. It was only after interviews with key university stakeholders that led us in such a direction. These interviewees noted that organizational objectives (the key reasons for the move to Division I) were not being met and that expenses were increasing sharply, revenues decreasing, and 
athletics was eating up a significant percentage of the college's modest endowment. Perhaps future research can explore additional dynamics of escalation.

\section{References}

Arkes, H.R., \& Blumer, C. (1985). The psychology of sunk cost. Organizational Behavior and Human Decision Processes, 35, 124-140.

Bouchet, A., \& Hutchinson, M. (2010). Organizational escalation to an uncertain course of action: A case study of institutional branding at Southern Methodist University. Journal of Issues in Intercollegiate Athletics, 3, 272-295.

Brockner, J., Rubin, J.Z., \& Lang, E. (1981). Face-saving and entrapment. Journal of Experimental Social Psychology, 17, 68-79.

Certo, S.T., Connelly, B.L., \& Tihanyi, L. (2008). Managers and their not-so-rational decisions. Business Horizons, 51, 113-119.

Cole, P., \& Wagnon, B. (2007). Are you ready for some football? Southern: The Official Publication of Birmingham-Southern College. Retrieved on February 7, 2011 from http://www.bsc.edu/communications/southern/summer07/features.pdf.

Collins, J.C., \& Porras, J.I. (1996). Building your company's vision. Harvard Business Review, 74, 65-77.

DeFord, F. (2007). Who's No. 1: Birmingham-Southern chose students over athletes. Sports Illustrated. Retrieved on April 7, 2010 from http://sportsillustrated.cnn.com/2007/ writers/frank_deford/01/10/birmingham.southern/.

Drummond, H. (1995). De-escalation in decision making: A case of a disastrous partnership. Journal of Management Studies, 32, 265-281.

Erlandson, D.A., Harris, E.L., Skipper, B., \& Allen, S.D. (1993). Doing naturalistic inquiry: A guide to methods. Newbury Park, CA: Sage.

Fox, F.V., \& Staw, B.M. (1979). The trapped administrator: Effects of job insecurity and policy resistance upon commitment to a course of action. Administrative Science Quarterly, 24, 449-471.

Frank, R.H. (2004). Challenging the myth: A review of the links among college athletic success, student quality, and donations. Knight Foundation Commission on Intercollegiate Athletics. Retrieved on February 2, 2011 from http://www.knightfoundation. org/ dotAsset/131763.pdf.

Freeman, R.E. (1984). Strategic management: A stakeholder approach. Boston, MA: Pitman.

Fulks, D.L. (2010). Revenues and expenses: NCAA Division I intercollegiate athletic programs report. Retrieved April 27, 2011 from http://www.ncaapublications.com.

Glesne, C. (1999). Becoming qualitative researchers: An introduction. New York, NY: Longman.

Goodman, P.S., Bazerman, M.H., \& Conlon, E.J. (1980). Institutionalization processes in organizational change. In B.M. Staw \& L.L. Cummings (Eds.), Research in organizational behavior (Vol. 2). Greenwich, CT: JAI Press.

Hearn, T. (2002). The culture of sport and the future of intercollegiate athletics association of governing boards. Boston, MA: Address to the Association of Governing Boards.

Keil, M., Tan, B.C.Y., Wei, K., Saarinen, T., Tuunainen, V., \& Wassenaar, A. (2000). A crosscultural study on escalation of commitment behavior in software projects. Management Information Systems Quarterly, 24, 299-325.

Kvale, S. (1996). Interviews: An introduction to qualitative research interviewing. Thousand Oaks, CA: Sage.

Lincoln, Y.S., \& Guba, E. (1985). Naturalistic Inquiry. Newbury Park, CA: Sage.

Lipshitz, R. (1995). The road to Desert Storm. Organization Studies, 16, 243-264.

March, J.G. (1978). Bounded rationality, ambiguity, and the engineering of choice. The Bell Journal of Economics, 9, 587-608. 
Marshall, C., \& Rossman, G.B. (1995). Designing qualitative research (2nd ed.). Thousand Oaks, CA: Sage.

Mertens, D. (1998). Research methods in education and psychology: Integrating diversity with quantitative and qualitative approaches. Thousand Oaks, CA: Sage.

Montealegre, R., \& Keil, M. (2000). De-escalating information technology projects: Lessons from the Denver International Airport. Management Information Systems Quarterly, 24, 417-447.

Moser, M. (2003). United we brand. Boston, MA: Harvard Business School Press.

Nisbett, R.E., \& Ross, L. (1980). Human inference: Strategies and shortcomings of social judgment. Englewood Cliffs, NJ: Prentice Hall.

Northcraft, G.B., \& Neale, M.A. (1986). Opportunity costs and the framing of resource allocation decisions. Organizational Behavior and Human Decision Processes, 37, 348-356.

Patton, M.Q. (1990). Qualitative evaluation and research methods (2nd ed.). Newbury Park, CA: Sage.

Patton, M.Q. (2002). Qualitative research and evaluation methods (3rd ed.). Thousand Oaks, CA: Sage.

Pfeffer, J. (1981). Power in organizations. Marchfield, MA: Pitman Publishing.

Platt, J. (1973). Social traps. The American Psychologist, 28, 641-651.

Powers, E. (2007). Tracking a move away from Division I. Inside Higher Ed. Retrieved on March 27, 2010 from http://www.insidehighered.com/news/2007/09/05/bsu.

Rice University Report. (2004). Intercollegiate athletics at Rice University. McKinsey Consulting. Retrieved on February 25, 2010 from http://professor.rice.edu/images/ professor/ report.pdf.

Ross, J., \& Staw, B.M. (1986). Expo 86: An escalation prototype. Administrative Science Quarterly, 31, 274-297.

Ross, J., \& Staw, B.M. (1993). Organizational escalation and exit: Lessons from the Shoreham Nuclear Power Plant. Academy of Management Journal, 36, 701-732.

Roy, D., Graeff, T., \& Harmon, S. (2008). Repositioning a university through NCAA Division I-A football membership. Journal of Sport Management, 22, 11-29.

Schwandt, T.A. (1997). Qualitative inquiry: A dictionary of terms. Thousand Oaks, CA: Sage.

Shimizu, K., \& Hitt, M.A. (2005). What constrains or facilitates divestitures of formerly acquired firms? The effects of organizational inertia. Journal of Management, 31, 50-72.

Simonson, I., \& Staw, B.M. (1992). De-escalation strategies: A comparison of techniques for reducing commitment to losing courses of action. The Journal of Applied Psychology, 77, 419-426.

Singer, J.N. (2009). African American football athletes' perspectives on institutional integrity in college sport. Research Quarterly for Exercise and Sport, 80, 102-116.

Soy, S.K. (1997). The case study as a research method. Unpublished paper, University of Texas at Austin. Retrieved on April 5, 2010 from http://www.ischool.utexas.edu/ ssoy/ usesusers/1391d1b.htm.

Staw, B.M. (1981). The escalation of commitment to a course of action. Academy of Management Review, 6, 577-587.

Staw, B.M. (2005). The escalation of commitment: Steps toward an organizational theory. In K.G. Smith \& M.A. Hitt (Eds.), Great minds in management (pp. 215-238). Oxford: Oxford University Press.

Staw, B.M., McKechnie, P.I., \& Puffer, S.M. (1983). The justification of organizational performance. Administrative Science Quarterly, 28, 582-600.

Staw, B.M., \& Ross, J. (1980). Commitment in an experimenting society: An experiment on the attribution of leadership form administrative scenarios. The Journal of Applied Psychology, 65, 249-260.

Staw, B.M., \& Ross, J. (1987). Knowing when to pull the plug. Harvard Business Review, $65,68-74$. 
Sull, D.N., \& Spinosa, C. (2007). Promise-based management. Harvard Business Review, $85,79-86$.

Tulane University Report. (2003). Report of the President. Retrieved on February 24, 2010 from http://pres2003.tulane.edu/home.html.

Urde, M. (2003). Core value-based corporate brand building. European Journal of Marketing, 37, 1017-1040.

Yin, R.K. (1984). Case study research: Design and methods. Newbury Park, CA: Sage.

Zillgitt, J. (2004). Vandy's athletics overhaul a novel, noble concept. USA Today. Retrieved on May 31, 2010 from www.usatoday.com/sports/columnist/ zillgitt/2004-03-23zillgitt_x.htm.

\section{Appendix A}

1. What is the annual budget for the athletic department?

2. What was the thought process in participating in Division I?

3. Did participating in Division I have an impact on enrollment?

4. When did participating in Division I athletics cease to be a good idea?

5. What factors contributed to BSC's decision to discontinue playing Division I athletics?

6. Discuss the political aspects of staying in (or moving to) Division I?

7. What is the relationship between the faculty and the athletic department?

8. Where did the President and the Board of Trustees stand regarding athletics?

9. How much influence did athletic department stakeholders play in their desire to discontinue participating in Division I athletics?

10. What participation did the Board of Trustees play in the decision-making process?

11. Who disagrees with the direction of intercollegiate athletics at this institution?

12. What was the most difficult part of leaving Division I?

13. How do universities stop or reposition their athletic department once it becomes clear that they are headed down a path of escalation of commitment? 